\title{
THE BALTIC STATES AFTER THE COLLAPSE OF THE SOVIET UNION
}

\author{
TOIVO U. RAUN \\ Indiana University, Bloomington, IN, \\ USA
}

At first glance it may appear that Estonia, Latvia, and Lithuania belong in a separate post-communist transitional category from the pace-setting former people's republics of East Central Europe such as Hungary, Poland, and the Czech Republic. As union republics of the USSR, the Baltic states were fully integrated into the Soviet political and economic system with virtually no opportunity for exercising autonomy in policymaking. Moscow's centralized control was evident in all phases of life, especially in the social policy of promoting massive in-migration of non-Balts that resulted in sweeping changes in ethnic composition during the decades of Soviet rule. Nevertheless, it is striking that the political and economic transition in the Baltic states during the 1990s most closely paralleled that of the Visegrád countries rather than that of other former Soviet republics. ${ }^{1}$ Historically, Estonia, Latvia, and Lithuania had experienced Central European, especially German and Polish, political and cultural hegemony, and they constituted the most Westernized and modernized parts of the USSR. Unlike other Soviet republics, they also benefitted from two crucial decades of independence during the 1920s and 1930s. It is thus no accident that the Baltic states played a key role in the collapse of the Soviet Union, particularly through the activism of such mass organizations as the Popular Fronts of Estonia and Latvia as well as Sajudis in Lithuania, all of which drew inspiration from East European models, especially Solidarity and the Prague Spring. The most significant difference between the Baltic states and the countries of East Central Europe in the twentieth century has been the greater geopolitical vulnerability in the Baltic case, as reflected in their location and size, although their current security concerns may well be mitigated by growing European and international integration. The following overview will stress the commonalities in the Baltic experience in the 1990s, but it also important to bear in mind the distinctive profile of each country.

The restoration of Baltic independence in August 1991 was the culmination of a long process that began more than five years earlier with demonstrations organized by the Latvian human rights group Helsinki ' $86 .{ }^{2}$ The East Central European events of 1989, especially in Hungary and Poland, and the withering away of the 
Brezhnev Doctrine provided significant encouragement for the Baltic movements and helped convince public opinion that renewed independence was indeed possible. Lithuania declared outright restoration of its independence on March 11, 1990, and Estonia and Latvia followed with declarations of a transition period toward the same goal on March 30 and May 4, respectively. The Kremlin refused to accede to these demands, but following a long political stalemate, the abortive August 1991 coup by desperate hard-liners in Moscow - by discrediting the strongest supporters of a highly centralized political system - suddenly made the reestablishment of Baltic independence feasible.

In all three Baltic states the domestic political transition was dominated by a similar process of relatively rapid democratization. The task of returning to constitutional rule based on Western models became the first order of the day. Latvia took the lead by declaring the restoration of the interwar Constitution of 1922 already in August 1991, and voters soon approved newly created constitutions in Estonia (June 1992) and in Lithuania (October 1992). In each case the emphasis was on continuity from the liberal democratic period (1920-1934 in Estonia and Latvia, 1920-1926 in Lithuania) of the interwar era. A restored unicameral parliament (the Estonian Riigikgu, the Latvian Saeima, and the Lithuanian Seimas) took the same name as in the 1920s and was intended to play the leading role in political life, particularly in Estonia and Latvia where the president was meant to be largely a figurehead, mainly performing symbolic functions. In Lithuania, on the other hand, the makers of the new constitution, following the views of Vytautas Landsbergis, the increasingly conservative head of Sajudis, created a rather strong presidency. Ironically, however, the first post-communist presidential elections in Lithuania in February 1993 resulted in victory not for the political right, but for the former leader of the Communist Party of Lithuania (CPL) Algirdas Brazauskas, who captured 60 percent of the total popular vote. ${ }^{3}$ His triumph points to a key political difference between Estonia and Latvia, on the one hand, and Lithuania, on the other, based on their experience under Soviet rule. In the northern two Baltic republics, the communist parties were never seen as representing the national interest, especially since native Balts were a bare majority (Estonia) or a minority (Latvia) of the membership, and as organizations, they faded from the scene with the fall of communism. In contrast, the CPL and its successor, the Lithuanian Democratic Labor Party, were viewed as legitimate national parties by most Lithuanians, and Brazauskas maintained a high level of personal popularity. ${ }^{4}$

Institutionalization of the electoral process is an important element in the consolidation of democracy. During the 1990s the Baltic states made significant progress in this direction as all elections, both national and local, were held as scheduled, and they were declared fair and free by international observers. Each country conducted regular parliamentary elections according to the respective 
constitutional guidelines: Estonia in 1992, 1995, and 1999; Latvia in 1993, 1995, and 1998; and Lithuania in 1992 and 1996. Presidential elections took place every three to five years. As befitted the greater power of the presidency in Lithuania, the elections were direct in that country while Latvia and Estonia chose their chief executives in the parliaments. The simple majority stipulated in the Latvian case presented no logistical problems, but in Estonia, the requirement of a two-thirds majority for the election of a president proved to be a difficult task in practice. In 1996, for example, the Riigikogu failed to agree on a successful candidate, and the election was thrown into the Electoral College, a larger body consisting of members of parliament and representatives of local government. Here the vote is by simple majority, but the procedure is cumbersome at best. ${ }^{5}$ On the local government level, elections were held every three years in each country. The distinctive feature of the Estonian case is that non-citizens are also permitted to vote in local elections, although only citizens may run for office. ${ }^{6}$

Perhaps the most striking aspect of the political transition in the Baltic states was the absence of violence, a key parallel with the situation in East Central Europe and a significant contrast with developments in the Balkans, the Caucasus, and Central Asia. Clearly, ethnic tensions and much economic hardship existed in the Baltic region, but they never spilled over into violence. With the minor exception of the unstable 1930s, the use of violence has never been part of modern Baltic political culture, and the Balts tended to look to the Nordic countires as models of stable development. As noted above, during the post-Stalin era, Baltic activists and intellectuals greatly admired the East European non-violent reform movements, especially the Prague Spring and Solidarity. Moreover, since Russians and other non-Balts were overwhelmingly recent immigrants, there was no long history of ethnic grievances to contend with in contrast to several other regions in the post-communist world. Finally, any use of violence by the Baltic peoples would have been counterproductive from their own point of view since the major potential antagonists were ethnic Russians, who were representatives of the hegemonic nationality of the Soviet empire and later the Russian Federation. It is worth recalling that according to the 1989 census, there were 145.1 million Russians in the Soviet Union and only 5.3 million Balts in Estonia, Latvia, and Lithuania. $^{7}$

Despite the positive trends noted above, there remains the question of how deeply democratic values have been internalized in the Baltic societies. In all three countries, voter participation in parliamentary elections declined substantially during the 1990s. In Estonia, the proportion of eligible voters taking part in the Riigikogu elections fell from 69 percent in 1995 to 57 percent in 1999. In Latvia and Lithuania, the rate of decline was even greater - from 90 percent (1993) to 72 percent (1995) in the Saeima elections and from 75 percent (1992) to 53 percent (1996) in the Seimas elections. ${ }^{8}$ Several factors contributed to this trend. Once 
independence had been reestablished and the initial contests for post-communist parliaments had taken place, there appeared to be considerably less at stake in later elections for many voters. Despite the positive macroeconomic indicators by the second half of the 1990s, there is also little doubt that the economic difficulties most people experienced in their daily lives contributed to a certain level of voter alienation. Furthermore, it is likely that various scandals associated with some leading politicians in all three Baltic states tended to increase cynicism among the public. Although the level of corruption in the Estonia, Latvia, and Lithuania was probably lower than in most post-communist countries, the public perception of it became more acute in the course of the 1990s. Fledgling political parties faced an enormous challenge in trying to overcome the legacy of the Soviet era and the profound cynicism it had fostered regarding any political organization, and opinion polls suggested that popular identification with political parties was low. Voters were clearly bewildered by the large, fragmented, and unstable party landscape which seemed to be in state of flux. In addition, political parties generally lacked a strong grass-roots base and were created from above by small elites with little participation from below. ${ }^{9}$

Another significant factor in assessing the process of democratization in the Baltic states is the question of citizenship, a particularly thorny issue in view of the major population changes that took place under Soviet rule. In the Lithuanian case there has been a remarkable stability in the proportion of the native population in the country despite all the upheavals of the twentieth century. In contrast, the Estonian and Latvian proportions of the population in their respective countries plummeted between the mid-1930s and 1989 (26.7 percentage points in Estonia and 23.7 in Latvia) while the ethnic Russian share more than tripled in both cases. Such a precipitous decline was unique among union republic nationalities in the former Soviet Union. On the eve of the collapse of the USSR, the Latvians comprised a bare majority in their homeland, and the Estonians constituted just over 60 percent in theirs. Although all three nationalities suffered the same kinds of population losses in the 1940s (mainly, Soviet deportations, wartime deaths, and flight to the West), the greater demographic dynamism in the Lithuanian case allowed them to maintain the native share of the population. Furthermore, this situation helped Lithuania to limit the in-migration of Russians and other nonBalts, a trend which Estonia and Latvia were much less able to withstand. ${ }^{10}$ As a result of these developments, in the early 1990s, Estonia and Latvia had the highest foreign-born populations in Europe (over 25 percent) after Luxemburg, while the proportion stood at just over 10 percent in the case of Lithuania. ${ }^{11}$

In view of the large non-native populations in their countries, the governments of Estonia and Latvia were reluctant to move rapidly on the citizenship issue before the restoration of independence for fear of committing themselves to a long- 
term solution before the question of political sovereignty was resolved. In contrast, the Lithuanian government, with a solid native majority in place, felt able to offer the "zero option" already in November 1989, i.e., citizenship (after a twoyear waiting period) to all permanent residents, who declared their loyalty to Lithuania. The great majority of non-Lithuanians in the country exercised this option, and thus the issue of voting rights was quickly settled in the Lithuanian case. In Estonia and Latvia, however, the process dragged on much longer. After the restoration of independence, in November 1991, Estonia reinstated its 1938 citizenship law, which meant that all persons who had been citizens in June 1940 and their descendants, regardless of ethnic background, were automatically considered citizens. All others desiring citizenship, including the great majority of the Russian and other non-Estonian population, had to follow a three-year naturalization procedure, including a modest level of competence in Estonian. ${ }^{12}$ In practice, this meant that the citizenship rolls would only expand incrementally. By 1999 the non-Estonian population in Estonia was divided as follows: about 30 percent were citizens of Estonia, nearly 20 percent were citizens of Russia, and about 50 percent were stateless. ${ }^{13}$ Clearly, this situation was not desirable from the point of view of political integration, and finding a workable solution remained a challenge for the Estonian authorities. In Latvia, where a citizenship law was passed only in July 1994, the process of inclusion was even more difficult, especially since a complicated timetable for eligibility slowed naturalization in the initial years of implementation. ${ }^{14}$

The evolution of the Baltic political systems in practice in the 1990s witnessed wide swings of the political pendulum in each country. In every succeeding parliamentary election the ruling party or coalition failed to retain its hold on power, largely because the voters blamed the existing government for the difficulties they had experienced during the post-communist transition. In Lithuania, the Democratic Labor Party's huge victory in 1992 was matched by a crushing defeat at the hands of the conservative Homeland Union in $1996 .{ }^{15}$ Despite a threshold of 4 or 5 percent in order to gain representation in parliament, Estonia and Latvia in particular were plagued with the problem of fragmentation and the multiplicity of political parties, a phenomenon that substantially complicated the formation of governing coalitions. In all three countries as well, the presidents proved to be the most popular politicians according to public opinion polls, probably because they were seen as standing above day-to-day politics and infighting. As suggested above, the political spectrum in the Baltic states was checkered and changing. Nevertheless, it can be argued that the basic political fault line in each country was already evident in the waning years of Soviet rule and continued during the 1990s, i.e., a division between "fundamentalists," who emphasized issues of principle and completely rejected the communist past, and the "pragmatists," who proceeded from 
the concrete situation at hand and were willing to make compromises in a less than ideal world. In the post-communist era the experience of governing narrowed the gap between these two broad groupings. ${ }^{16}$

Since the first period of Baltic independence ended with the military occupation and forced annexation of Estonia, Latvia, and Lithuania by the Soviet Union, security issues played a major role in the transition of the 1990s. Given geopolitical realities and the legacy of the recent past, it was clear that Baltic relations with the Russian Federation would be the most important challenge in this decade. During these years, Russia struggled with its own post-Soviet identity crisis, which was further exacerbated by continuing economic and political instability. A substantial proportion of its political and military elites still exhibited an imperial mentality, and as former Soviet republics, which had been part of the Russian Empire since the eighteenth century, the Baltic states were generally viewed as part of the "near abroad" (Russ. blizhnee zarubezh'e), i.e., within a special sphere of influence reserved for Russia. In the early 1990s the issue of ex-Soviet troops in Estonia, Latvia, and Lithuania dominated all others, since their presence was a continuing affront to Baltic sovereignty. From a total of about 300,000 troops in the Brezhnev era, the numbers declined quickly in the glasnost' era and the early 1990 s to some 30,000 in July 1993. In large part because of its relatively small Russian minority, Lithuania's relations with Russia were the smoothest among the Baltic states, and it was not surprising that ex-Soviet troops left that country first in August 1993 and only in August 1994, after considerable pressure from the West, did they agree to leave Estonia and Latvia. ${ }^{17}$

Nevertheless, Lithuania continued to face the unique question of Russian land access to Kaliningrad, the anomalous ex-Soviet exclave and prize of World War II to its west. In the second half of the 1990s, Russia dragged its feet on a final resolution of border issues with Estonia and Latvia and often criticized the treatment of the large Russian minorities in the two countries. It is also noteworthy that Russia has refused to accept responsibility for Soviet actions in the Baltic states or to apologize for them, in contrast to its willingness to do so for the Katyn massacre in the case of Poland and the Winter War with Finland. ${ }^{18}$ However, there were also indications that the priority assigned to the Baltic states in Russian foreign policy towards former Soviet republics was in decline, particularly in comparison to such larger entities as Ukraine, Belarus, and Kazakhstan.

In order to balance the unsettled relations with Russia and to return to the European and international community of nations, which they had been part of during the interwar era, the Baltic states placed great emphasis on integration with Europe and the West in the 1990s. Following quick admission to the United Nations and the Conference (later, Organization) on Security and Cooperation in Europe in fall 1991, Estonia, Latvia, and Lithuania became founding members of the Council of Baltic Sea States (CBSS) in March 1992, a ten-country regional 
organization that also included the Nordic states, Germany, Poland, and Russia. The CBSS was particularly attractive to small countries such as the Baltic states, not only as a means to foster regional cooperation in a number of areas but also to moderate the powerful influence of large states such as Russia and Germany. ${ }^{19}$ An important milestone in the early independence years for all three Baltic states was admission to the Council of Europe (Estonia and Lithuania in May 1993, Latvia in February 1995) since its membership criteria demanded adherence to strict standards on democratic elections and human rights.

By the second half of the 1990s, the foreign policy of the Baltic states focused increasingly on gaining membership in the European Union and NATO. In June 1995, the EU concluded similar association agreements with all three Baltic countries, but Estonia's alone did not stipulate a transition period. In July 1997 Estonia was invited, along with Poland, the Czech Republic, Hungary, Slovenia, and the Greek portion of Cyprus, to enter into negotiations for EU membership in the next round of expansion. Although Estonia argued that the entry of one Baltic state into the EU would open the door for the other two, it was clear that the exclusion of Latvia and Lithuania from this first group of candidates raised intra-Baltic tensions. Nevertheless, in December 1999 Latvia and Lithuania joined Slovakia, Romania, Bulgaria, and Malta as additional EU candidate members, and it remained possible that Estonia's two southern neighbors could catch up in the negotiations. ${ }^{20}$ However, the pace of the projected EU expansion would clearly be uncertain since it depended on a wide range of factors, not the least of which was the organization's capacity for internal reform. None of the Baltic states was selected by NATO for its first round of post-Cold War enlargement in which Hungary, Poland, and the Czech Republic became full members in March 1999, and the governments of Estonia, Latvia, and Lithuania repeatedly expressed concern about the possibility of a "gray zone" of insecurity emerging between a partially expanded NATO and Russia, as Baltic-NATO negotiations continued. Among the Baltic states in the year 2000, Lithuania was best prepared to enter NATO, but in all three countries, a growing public debate was joined about the cost of association. Public opinion regarding possible membership in both the EU and NATO during the second half of the 1990s showed considerable volatility. ${ }^{21}$

An intriguing issue regarding the post-communist Baltic states is the extent to which they will develop a substantive regionalism and sense of solidarity. The historical record of Baltic cooperation in the interwar period was rather dismal, dramatically illustrated by their inability to come together in a united front in the crisis of 1939-1940. However, the common experience under Soviet rule brought the Balts closer together, and the height of cooperation clearly came during the glasnost' years when the need for solidarity against Moscow was greatest. Following the restoration of independence, each Baltic state tended to follow its own path, seeking to develop ties to its richer and more powerful neighbors. For exam- 
ple, Estonia strengthened its already strong connections to Finland, and Lithuania formed a new alliance with Poland that moved beyond their troubled historical relations. Relations between the Baltic states became tense at times in the 1990s over oil deposits and fishing rights in the Baltic Sea and over trade disputes. On the other side of the coin, the three countries did show solidarity in foreign policy toward Russia, and military cooperation, especially the formation of the Baltic Battalion in September 1994, went much further than during the 1920s and 1930s. ${ }^{22}$ In addition, with the opening up of the entire Baltic Sea region in the post-Cold War era, Estonia, Latvia, and Lithuania had an important model in the neighboring Nordic countries with their long experience in regional cooperation.

One of the most difficult challenges facing the post-communist states was the necessity of simultaneously coping with the political and the economic transition. Nevertheless, in the economic realm as well, the Baltic states outpaced the other former Soviet republics and achieved considerable macroeconomic success, although not on the level of the Czech Republic or Hungary. Led by Estonia, the Baltic states quickly established new currencies and thus escaped the "ruble zone," which in turn allowed them to bring inflation under control. They were also able to diversify their trade relations and move away from strong dependence on Russia as a commercial partner. By 1998 Estonia and Latvia (whose main trading partners were Finland and Germany, respectively) had the most success in this regard, as in both cases trade with Russia only comprised about 12 percent of the total. For Lithuania, Russia remained the leading partner, but the share of this trade had fallen to less than 20 percent of the country's total in 1998. Following the inevitable economic downturn in the early transition years, all three countries showed strong economic growth during most of the second half of the 1990s. However, their continuing vulnerability to events in Russia was demonstrated by the negative growth rates in each Baltic state in 1999, a direct result of the impact of the Russian financial crisis of August 1998. Per capita GDP was highest in Estonia as was direct foreign investment, the latter clearly encouraged by the country's liberal economic policies. ${ }^{23}$

Despite this relatively strong economic performance in the 1990s, the actual impact of the transition on the daily lives of much of the population in the Baltic states was no doubt painful. As elsewhere in the post-communist world, there was substantial socioeconomic dislocation and a heightening of inequality of income and wealth. The gap in standard of living between urban and rural areas and between richer and poorer regions of each country increased, and generational differences also grew, as older workers and retired persons found it harder to adjust to the new conditions of a free market. As measured by Eurostat's purchasing power standard (PPS), the average living standard in Estonia at the end of the 1990 s was only slightly more than one-third of the EU average, while in Lithuania 
and Latvia it was about one-third and one-fourth, respectively. Even in relatively well-off Estonia, the per capita GDP was only one-seventh of that of neighboring Finland. ${ }^{24}$

With regard to society, the greatest challenge for the Baltic states was coming to terms with the sweeping population changes brought about under Soviet rule, especially in Estonia and Latvia. As can be seen in Table 2, the native proportion of the population crept upward in these two countries in the 1990s, mainly due to out-migration of Russians and other non-Balts. However, by the late 1990s, emigration slowed to a trickle and became a minor factor in the demographic balance sheet. As Baltic politicians assessed their options in the post-communist years, it became increasingly clear that the only viable alternative was integration, i.e., the goal of a tolerant multicultural society in which each ethnic group retained it separate cultural identity, but also acquired a common civic identity based on loyalty to the given Baltic state and a working knowledge of the state language. ${ }^{25}$ It was obvious that creating such a common identity in each of the Baltic countries would require enormous resources and good will on all sides and that integration would be a long-term process. There was also little doubt that a fully reformed and effective educational system would have to play a major role in achieving this goal.

In conclusion, it may be noted that there were numerous parallels between the post-communist transitions in the Baltic states and those in East-Central Europe, including substantial progress toward democratization, absence of violence, macroeconomic success, and growing participation in the process of European and Western integration. Nevertheless, distinctive features could also be found in the Baltic case, especially the challenges of integrating large numbers of non-Baltic immigrants from the Soviet era and reaching a viable modus vivendi with Russia after fifty years of Soviet occupation and rule. Among the smallest states in Europe in terms of population, Estonia, Latvia, and Lithuania debated the future of their identity during the 1990s as part of an integrating continent and a globalizing world. The recent experience of their northern neighbor Finland, an EU member since 1995, suggested that a national and a European identity could coexist in a small country.

\section{Notes}

1. See, for example, Karen Dawisha and Bruce Parrott, eds, The Consolidation of Democracy in East-Central Europe (Cambridge, 1997), which has chapters on Hungary, Poland, the Czech Republic, Slovakia, Latvia, Lithuania, and Estonia.

2. For brief overviews, see Alfred Erich Senn, "Lithuania's path to independence," Journal of Baltic Studies, 22 (1991), 245-250; Toivo U. Raun, "The re-establishment of Estonian independence," ibid., 251-258; and Andrejs Plakans, "Latvia's return to independence," ibid., 259266. 
3. Alfred Erich Senn, "Lithuania: Rights and responsibilities of independence," in: Ian Bremmer and Ray Taras, eds, New States, New Politics: Building the Post-Soviet Nations (Cambridge, 1997), 363-365; Richard J. Krickus, "Democratization in Lithuania," Dawisha and Parrott, Consolidation of Democracy, 305.

4. The Lithuanian share of CPL membership showed a clear upward trend during the Soviet era. For comparative statistics on the native role in Baltic communist parties, see Romuald J. Misiunas and Rein Taagepera, The Baltic States: Years of Dependence, 1940-1990, expanded and updated ed. (Berkeley, Calif., 1993), 359-360.

5. Republic of Estonia Constitution (Tallinn, 1993), 25.

6. Ibid., 44. A residency requirement of five years was dropped before the October 1999 local elections, making it easier for non-citizens to vote.

7. Toivo U. Raun, "Ethnic relations and conflict in the Baltic states," W. Raymond Duncan and G. Paul Holman, Jr., eds, Ethnic Nationalism and Regional Conflict: The Former Soviet Union and Yugoslavia (Boulder, Colo., 1994), 171-174.

8. Rein Taagepera, "Valimisreeglid Eestis aegade jooksul," Riigikogu valimised 1999 (Tartu, 1999), 23; Andrejs Plakans, "Democratization and political participation in postcommunist societies: The case of Latvia, Dawisha and Parrott," Consolidation of Democracy, 281; Krickus, "Democratization in Lithuania," 303; Lietuvos statistikos metraštis 1998 (Vilnius, 1998), 55. The figure for Lithuania in 1996 is only for the first round of parliamentary elections.

9. Rain Rosimannus, "Political parties: Identity and identification," Nationalities Papers, 23 (1995), 36-39. For an overview of the changing Baltic party landscape in the 1990s, see Vello Pettai and Marcus Kreuzer, "Party politics in the Baltic states: Social bases and institutional context," East European Politics and Societies, 13 (1999), 184-189.

10. Raun, "Ethnic relations and conflict," 158-160.

11. Kalev Katus, "Estonia and Europe: Population dimension," Society, Parliament and Legislation (Tallinn, 1999), 134.

12. Dzintra Bungs, Saulius Girnius, and Riina Kionka, "Citizenship legislation in the Baltic states," RFE/RL Research Report, 1, no. 50 (1992), 38-40; Riigi Teataja, no. 7 (1992), 175-176.

13. Estonian Human Development Report 1999 (N.p., 1999), 40-43.

14. Nils Muiñnieks, "Making citizenship work," The Baltic Times, March 13-19, 1997, 23.

15. The Baltic Times, November 14-20, 1996, 1.

16. Toivo U. Raun, "Democratization and political development in Estonia, 1987-1996," Dawisha and Parrott, Consolidation of Democracy, 347, 361.

17. Raun, "Ethnic relations and conflict," 162-63, 179; New York Times, July 27, 1994, A1.

18. Luup, June 29, 1998, 29.

19. Eve Kuusmann, "Estonia and cooperation in the Baltic Sea region," Pertti Joenniemi and Peeter Vares, eds., New Actors on the International Arena: The Foreign Policies of the Baltic Countries (Tampere, 1993), 83-93.

20. The Baltic Independent, June 16-22, 1995, 1; The Baltic Times, July 27-23, 1997, 1, 8; December 16, 1999-January 5, 2000, 1, 3.

21. Postimees, December 17, 1999, 11.

22. Postimees, October 25, 1999, 9; Mare Haab, "Potentials and vulnerabilities of the Baltic states: Mutual competition and cooperation," Birthe Hansen and Bertel Heurlin, eds., The Baltic States in World Politics (New York, 1998), 10-11.

23. Estonian Institute of Economic Research, Baltic Facts 1999 (Tallinn, 1999), 21, 67-69; Statistical Yearbook of Estonia 1999 (Tallinn, 1999), 352-353; Postimees, September 29, 1999, 11.

24. Helsingin Sanomat, April 21, 2000, C1; May 15, 1999 , B7.

25. Mati Heidmets, “The Russian minority: Dilemmas for Estonia,” Trames, 2 (1998), 264-272. 